\title{
Archivist's Career in the 21st Century: The Road to Success
}

\section{Yüzyılda Arşivcinin Kariyeri: Başarıya Giden Yol}

\author{
Burçak Şentürk ${ }^{1}$ [1]
}

${ }^{1}$ Assoc. Prof. Dr. Marmara University, Faculty of Arts and Sciences, Department of Information and Records Management, Istanbul, Turkey

ORCID: B.Ş. 0000-0001-5780-8324

Corresponding author/Sorumlu yazar: Burçak Șentürk,

Marmara University, Faculty of Arts and Sciences, Department of Information and Records Management, Istanbul, Turkey

E-mail: burcaksenturk@gmail.com

Submitted/Başvuru: 12.10.2021

Revision Requested/Revizyon Talebi: 02.11.2021 Last Revision Received/Son Revizyon: 02.11.2021 Accepted/Kabul: 29.11.2021

Published Online/Online Yayın: 09.12.2021

Citation/Atıf: Senturk, B. (2021). Archivist's career in the 21st century: the road to success. Bilgi ve Belge Araștırmaları Dergisi, 16, 81-102. http://doi.org/10.26650/bba.2021.16.1008524

\begin{abstract}
The word 'career' can be perceived by people in different ways. In this context, the titles of life career, family career and business career have settled in the literature. The subject of this study is about business career. In order to draw a career path in business life and to achieve success, many methods, techniques, training programs, etc. are being developed from day to day. However, it is an undeniable fact that some knowledge, skills and competencies have preserved their place from past to present. Archival profession, which is accepted as one of the oldest professions in the world, is changing its face day by day with the changing world conditions. Today, in order to be a successful archivist, it is inevitable to combine many knowledge, skills and competencies. In this study, the concepts of a profession in archives management and career are discussed together and the important points on the basis of being a successful archivist in the 21 st century are discussed. For this purpose, a comprehensive literature analysis has been made on the subjects, all the studies examined, and the method of content analysis has been carried out.
\end{abstract}

Keywords: Archivist, career, 21st century, success

ÖZ

Kariyer kelimesi insanlar tarafindan farklı şekillerde algılanabilir. Bu bağlamda literatüre de yaşam kariyeri, aile kariyeri ve iş kariyeri başlıkları yerleşmiştir. Bu çalışmanın konusu iş kariyeridir. İş hayatında kariyer yolu çizmek ve başarıyı yakalayabilmek için günden güne birçok yöntem, teknik, eğitim programları vb. geliştirilmektedir. Ancak geçmişten günümüze birtakım bilgi, beceri ve yetkinliklerin de yerini koruduğu yadsınamaz bir gerçektir. Dünyanın en eski mesleklerinden biri olarak kabul edilen arşivcilik de değişen dünya şartları ile birlikte çehresini günden güne değiştirmektedir. Günümüzde başarılı bir arşivci olabilmek için birçok bilgi, beceri ve yetkinliğin birarada olması kaçınılmazdır. Bu çalışmada, arşivcilik ile kariyer kavramları birarada ele alınarak 21. Yüzyılda başarılı bir arşivci olabilmenin temelindeki önemli noktalar üzerinde durulmaktadır. Bu amaçla konuya yönelik kapsamlı bir litetatür analizi yapılmış tüm çalışmalar incelenerek, içerik analizi yöntemi ile konu ele alınmıştır. Anahtar kelimeler: Arşivci, kariyer, 21. yüzyıl, başarı 


\section{INTRODUCTION}

Career is one of the basic concepts of human resource management. The main reason why the concept of career management is given importance in the business literature is that intellectual capital is seen as the most important business investment today. Regardless of the occupation or the job, managing and planning the career and determining the career path are very important for success.

The basic mission of archives management is the preservation and at the same time making available the information/record (archival material) that is strategic for societies, governments and institutions. At this point it would not be wrong to say 'managers of the memory' for archivists. In this context, archivists are employed in a very wide area like government agencies, universities, historical associations, corporations, hospitals, professional associations, colleges, museums, research centers, and religious organizations.

In this study, the topics of career and the archival profession were brought together. For this purpose, first the concept of a career and success within careers in the 21 st century have been examined. Afterwards, the issue of career in the archival profession in the 21 st century was discussed. In this section, besides the career of the archivist, the changes in the definition and mission of the archivist from Jenkinson to the present are revealed, and the basic competencies and skills that the archivist should have, as well as the things that must be accomplished in order to have a successful career are discussed. In the study, the archival profession has been discussed in general, regardless of the archive type in which the archivist takes charge.

It has been observed throughout the literature analysis that the career phenomenon in the archival profession is hardly studied. In this sense, it is anticipated that the study will shed light on the career field in archives management.

This study entitled “Archivist's Career in the 21st Century: The Road to Success" seeks to answer the following questions:

- What are the skills and competencies that the archivist should have for a successful career pathway and career fulfillment?

- What should the archivist pay attention to in order to progress in a successful career pathway? and

- What should be the basic elements that should be included in the mission statement of the "Highly Skilled 21st Century Archivist"?

A comprehensive literature analysis was made on the subjects of 'archivist's career' and 'career management in the archival profession' while searching for answers to the questions above within the scope of the study. The subject was discussed with the content analysis method. 


\section{The Concept of Career and Success in the 21st Century}

\subsection{The Concept of Career}

Career, in its most basic sense, is the specialization of a person in a certain field. The concept of career includes the concepts of profession, progress, and work sequence and can be used instead of these concepts.

Brewer (2020, p. 4) defines career as: "A career signifies a particular, bounded function with skills, knowledge and attributes attached. It is a way of seeing, knowing and understanding the world". Brewer's definition of career expresses the career concept of the 21st century. As can be understood from the definition, career should not be seen as a narrow-scoped concept, but rather as a comprehensive element that requires knowing oneself very well and having a vision.

Career is a long-term phenomenon. It is a process that includes individuals' all occupations that they have throughout their life. It is wrongly known by people that while promotions are a part of career, some negative circumstances and demotions are not included in one's career journey. However, like promotions, demotions are also a part of career (Cicek, 2021, p. 10).

Careers single out lives and shape them in profound ways. The notion of a career is not a straightforward concept and, increasingly, it has become more complicated. Many young people today will have multiple careers in diverse industries (Brewer, 2020, p. 3).

The point of view on the concept of career has been changed in recent years due to some environmental and technological changes. However, significant differences between generations have greatly changed human perceptions and expectations. This situation is reflected in the understanding of career and the business world has entered a compulsory transformation.

In the 21st century career concept, material factors such as salary increase and promotion have largely been replaced by job satisfaction. Vertical structuring in institutions is now replaced by horizontal structuring where hierarchy is less and effective communication gains importance. The employee has begun to be given more responsibility and authority to take initiative. And most importantly, work experience and networking, which have begun to lose the priority of formal education today, have gained importance.

\subsection{Success in the 21st Century}

'Success in the 21st Century' is a frequent topic of popular management books, social media, and corporate training for management gurus etc. There have been so many studies on this topic that it is not possible to compile them all in this section, so the key points related to the subject have been examined. 
The main criteria of success in the 21 st century, as mentioned before, are first of all to know oneself, having a vision, and then to take the responsibility of managing one's career and make career planning. Experts describe this situation as follows:

Traditional career theories typically view the organisation's needs as the primary consideration in career development decisions and view the employee's needs as secondary. From the protean perspective, however, the individual is seen as 'the figure' and the organisation is conceived as 'the ground' or context in which the protean worker can realise his or her aspirations. In this new relationship, the burden of responsibility for career development is shifted from the organisation to the individual and thus requires that protean workers self-manage their careers (Donohue and Tham, 2019, p. 55).

In this context, the necessity of the archivist to have the responsibility of managing her/ his own career emerges.

In addition to the responsibility of career management, the main qualities that a successful business person of the 21 st century should have been determined in many studies.

Tom Peters, a famous business guru lists the characteristics of 'resilient people' in the business world in his blog post titled "Resilience and Black Swans" (Peters, 2021):

- Inner calm,

- High self-knowledge,

- Breadth of experience,

- Lover of modestly controlled chaos,

- Reach out effortlessly to a wide variety of people,

- Bizarrely energetic,

- Known for integrity, in the sense of "straight shooter",

- Hires resilient people per se in key positions,

- Sense of humor,

- Empathy ("I feel your pain”),

- "Cruelty" (Must make tough decisions instantaneously, without looking back; not "confident," but overwhelming sense of urgency to press ahead),

- Decisive, but not rigid, 
- Strong individual, equally strong team player,

- Understands the chain of command - and evades it as necessary and

- Comfortable being challenged by thinkers, but a strong "doer" bias overall

The characteristics mentioned by Peters above also shed light on the point of successful career concepts and criteria today.

In an important study that deals with human resources management with an Industry 4.0 perspective, required competencies have been comprehensively established in 4 basic categories.

Table 1: Set of competencies by their categories

\begin{tabular}{|c|c|c|}
\hline Category & Required competencies & Context \\
\hline 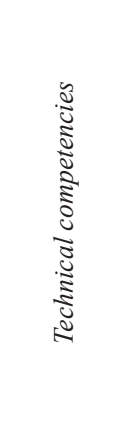 & $\begin{array}{l}\text { State-of-the-art } \\
\text { knowledge } \\
\text { Technical skills } \\
\text { Process understanding } \\
\text { Media skills } \\
\text { Coding skills } \\
\text { Understanding IT } \\
\text { security }\end{array}$ & $\begin{array}{l}\text { Due to increasing job responsibility knowledge is getting } \\
\text { increasingly important } \\
\text { - Comprehensive technical skills are needed to switch from } \\
\text { operational to more strategic tasks } \\
\text { - } \quad \text { Higher process complexity demands a broader and deeper process } \\
\text { understanding } \\
\text { - Increasing virtual work requires employees to be able to use } \\
\text { - } \quad \text { Growth media, e.g., smart glasses } \\
\text { employees with coding skills } \\
\text { Virtual work on servers or platforms obligates employees to be } \\
\text { aware of cyber security }\end{array}$ \\
\hline 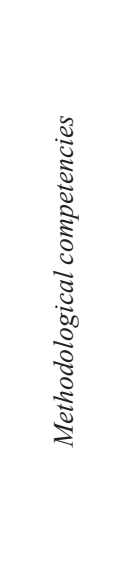 & $\begin{array}{l}\text { Creativity } \\
\text { Entrepreneurial thinking } \\
\text { Problem solving } \\
\text { Conflict solving } \\
\text { Decision making } \\
\text { Analytical skills } \\
\text { Research skills } \\
\text { Efficiency orientation }\end{array}$ & $\begin{array}{l}\text { - } \\
\text { - } \quad \text { Eveed for more innovative products, as well as for internal } \\
\text { Every employee with more responsible and strategic tasks has to } \\
\text { act as an entrepreneur } \\
\text { Employees must be able to identify sources of errors and be able } \\
\text { to improve processes } \\
\text { - A higher service-orientation increases customer relationships; } \\
\text { conflicts need to be solved } \\
\text { - Since employees will own higher process responsibility, they } \\
\text { have to make their own decisions } \\
\text { - Structuring and examining large amounts of data and complex } \\
\text { processes becomes mandatory } \\
\text { Need to be able to use reliable sources for continuous learning in } \\
\text { changing environments } \\
\text { Complex problems need to be solved more efficiently, e.g., } \\
\text { analyzing growing amounts of data }\end{array}$ \\
\hline
\end{tabular}




\begin{tabular}{|c|c|c|}
\hline 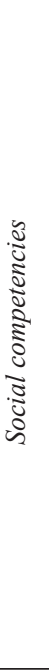 & $\begin{array}{l}\text { Intercultural skills } \\
\text { Language skills } \\
\text { Communication skills } \\
\text { Networking skills } \\
\text { Ability to work in a team } \\
\text { Ability to be } \\
\text { compromising and } \\
\text { cooperative } \\
\text { Ability to transfer } \\
\text { knowledge } \\
\text { Leadership skills }\end{array}$ & $\begin{array}{l}\text { - Understanding different cultures, especially divergent work } \\
\text { habits, when working globally } \\
\text { Being able to understand and communicate with global partners } \\
\text { and customers } \\
\text { - Service-orientation demands good listening and presentation } \\
\text { skills, whereas increasing virtualwork requires sufficient virtual } \\
\text { communication skills } \\
\text { - Working in a highly globalized and intertwined value chain } \\
\text { requires the knowledge networks } \\
\text { Growing team-work and shared work on platforms expects the } \\
\text { ability to follow team rules } \\
\text { Entities along a value chain develop to equal partners; every } \\
\text { project needs to create win-win situations, especially in } \\
\text { businesses with increasing project work } \\
\text { Companies need to retain knowledge within the company; } \\
\text { especially with the current demographic change, explicit and tacit } \\
\text { knowledge needs to be exchanged } \\
\text { More responsible tasks and flattened hierarchies make every } \\
\text { employee becoming a leader }\end{array}$ \\
\hline 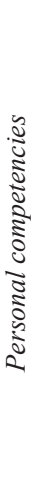 & $\begin{array}{l}\text { Flexibility } \\
\text { Ambiguity tolerance } \\
\text { Motivation to learn } \\
\text { Ability to work under } \\
\text { pressure } \\
\text { Sustainable mindset } \\
\text { Compliance }\end{array}$ & $\begin{array}{l}\text { - Increasing virtual work makes employees become time and place } \\
\text { independent; work-task rotation further requires employees to be } \\
\text { flexible with their job responsibilities } \\
\text { - Accepting change, especially work-related change due to work- } \\
\text { task rotation or reorientations } \\
\text { - More frequent work related change makes it mandatory for } \\
\text { employees to be willing to learn } \\
\text { Employees involved in innovation processes need to cope with } \\
\text { increased pressure, due to shorter product life cycles and reduced } \\
\text { time-to-markets } \\
\text { As representatives of their companies, employees also need to } \\
\text { support sustainability initiatives } \\
\text { Stricter rules for IT security, working with machine, or working } \\
\text { hours }\end{array}$ \\
\hline
\end{tabular}

Source: Hecklaua, Fabian and others. (2016). Holistic approach for human resource management in Industry 4.0". Procedia CIRP, 54, p. 4.

Many different ideas have emerged in hundreds of studies on the answer to the question of how to achieve success in the 21st century. However, in order to achieve success today, it is important to be aware of one's individual abilities and interests, to search for career opportunities, to define career goals, and to create a road map to reach this goal. Afterwards, forming an individual vision based on one's work experience, directing business relations correctly, and developing a wide communication network are the key success factors.

\section{Archivist's Career in the 21st Century}

\subsection{The Mission of The Archivist}

The definition of the job is a strategic issue in career management. Because the definition of the job will form the basis for the success criteria. In this context, defining the archivist and the 
basic roles and duties are one of the important requirements of career planning. An archivist can simply be defined as a person who manages archival material in line with archival principles and practices. However, the archival profession, of course, goes far beyond this definition.

Archivist is defined in the dictionary of The Society of American Archivist as follows:

1. An individual responsible for appraising, acquiring, arranging, describing, preserving, and providing access to records of enduring value, according to the principles of provenance, original order, and collective control to protect the materials' authenticity and context. 2. An individual with responsibility for management and oversight of an archival repository or of records of enduring value (Pearce-Moses, 2005, p. 33).

In the dictionary of the American Library Associations, the archivist is defined as:

1. The person in charge of an archival repository. 2. A person responsible for any of the tasks engaged in archival (1) work, including accessioning, appraisal (2), arrangement (3), description, disposition, exhibition, preservation, and reference services (Levine-Clark and Carter, 2013, p. 15).

The basic roles and duties of the archivist were considered only as the basic functions of archives management, and the mission of the archivist was adopted as the preservation and use of archival material. Today, however, the archival profession is changing in line with both the importance given to the profession and technological advances. We can see this change in the work of experts from past to present.

Jenkinson, who is one of the masters of archives management, explains the mission of the archivist as:

the duties of The Archivist are primary and secondary. In the first place he has to take all possible precautions for the safeguarding of his Archives and for their costody, which is the safeguarding of their essential qualities. Subject to the discharge of these duties he has in second place to provide to the best of his ability for the needs of historians and other research workers. But the position of primary and secondary must not be reversed (Jenkinson, 1965, p. 15).

Dearstyne, on the other hand, conveyed the roles of archivists at SAA Role Designation as follows: (Dearstyne, 1993, pp. 11-14):

- Archivists are the arbiters in decisions of whether to keep or discard records.

- Archivists assert control and bring order. 
- Archivists encourage use of historical records and serve researchers.

- Archivists preserve and protect historical records.

- Archivists promote and advocate.

- Archivists prepare for and help shape the emerging information universe.

- Archivists are program managers.

Millar (2017, pp. 68-70) identified the basic missions of the 21 st century archivist as four distinct actions in her recent study as follows:

- Redefine archives to meet twenty-first-century realities,

- Incorporate recordkeeping requirements into technology,

- Increase the archival role as advisors and consultants and

- Engage with the public to raise awareness.

It is also important to clarify the main goals and objectives, which include the purpose of existence and basic principles in determining the success criteria of the profession in career management. At this point, professional organizations have a great responsibility.

On the website of the International Council on Archives, the aims of an archivist are discussed under the heading "Who is an archivist?" as follows (ICA, 2021):

- Create a coherent collection through well-informed and pro-active selection and collecting,

- Effective collection management which ensures the long-term physical survival of collections, the creation of reliable and detailed information about the content of the collections and sustainable care to ensure the long-term survival of collections,

- A coherent access programme which ensures that anyone that wants to use the contents of the archive can easily find out about the collection and access its contents in a way convenient to their own needs and

- Collaboration with others to exploit synergies between archive collections and maximise opportunities for using and preserving collections.

In another study, Williams; explains the duties of the archivist from a broad perspective as follows: The chief mission of the archivist is to select, preserve and make available the archives in hir or her care. They consider the cultural and social value of the records alongside their buniess and legal value. They work in a range of contexts. In one model the archivit maintains the archives of his or her parent body, whether a government, organisation or institution, firstly for their administrative usefulness to the creators or their successors. Archivists also work in 
environments where the link with their employer is tied in less with the management of the organisation's own records than with managing collections taken in from external sources, in line with a specific acquisition or collection policy. Here the archivist will select, preserve, arrange, descibe and make accessible these to a wider client group and for a wider range of research purposes (Williams, 2006, pp. 20-21).

The role of the archivists have been considered from the following perspectives in the manifesto published by the Italian archivists in 2016 (ICA, p. 3):

- the past, by correctly preserving - and making available for consultation - the documents that have been selected for their permanent historical and judicial value,

- the present, by contributing to both the organisation and the running of current records, which are tools of administrative efficiency and democratic transparency,

- the future, by safeguarding, by means of careful strategies, bigger and bigger archives which are more and more fragile due to the increasing obsolescence of new technologies.

Career management as an important field of business science is dynamic. However, when it comes to professions, it is also important to draw a portrait of each profession and to serve as a basis for the permanent principles of this portrait and possible changes.

Bruce Dearstyne explains the general portrait of archivist in his study entitled "The Archival Profession: Meeting Critical Institutional and Social Needs" as:

Professional archivists, through a combination of education and experience, are qualified to identify, manage, preserve, and make available records with enduring value for documentation, research, and other purposes. They are employed in businesses, governments, universities, historical societies, libraries, museums, and other institutions that create and wish to maintain important records of their own, or that collect and maintain records for research use (certifiedarchivists.org, 2021).

\subsection{1st Century Archivist}

Technical innovations largely form the basis of 21 st century professions. When it comes to archives management, changes in information technology form the basis. This has been emphasized in recent studies. These studies also emphasize the points that the 21 st century archivist should pay attention to in the career management processes.

For the archivist, in a purely practical sense, all these developments in cyberspace mean that an online catalogue and a website are now standard requirements of every record office, and an Internet connection is expected. It means that the archivist now needs to be skilled in old and new techniques, familiar on the one hand with medieval diplomatic documents and 
on the other with the requirements of searching for genealogical and historical information on the Web (Craven, 2008, p. 8).

Archivists need to know how information technology is applied to recordkeeping and to the management of records. The needs in the two areas complement each other. Learning in both areas should proceed from a solid understanding of archival theory and method in order to ensure the protection of the integrity of archives as evidence of decision and action (Eastwood, 1993, p. 458).

Stevenson (2008, p.88) explains the points to be considered under the title of information professionals in detail with the following sentences:

Information professionals are increasingly taking a more user-centred approach to their work. Many of the latest technical innovations encourage individuals to become empowered to create, manipulate and use information in ways not previously envisaged. In this climate, the methods that individuals use to discover and interact with archive materials are going to continue to develop at a fast pace, and we can have little idea what may lie in store in ten or twenty years' time. There is likely to be a move away from the traditional view of the professional as gatekeeper and controller of resources, but what does this mean for the role of the archivist of the future? We cannot predict what is going to happen in the fast-paced world of technology, but what we can do is to ensure that we are aware of technical developments and trends, so that we can take the opportunities that technology provides to enhance and improve what we do and meet users' needs as effectively as we can.

Hilary Jenkinson, in his article titled

Reflections of an Archivist", expresses from a broad perspective on which subjects a successful archivist should have knowledge and skills (1984, p.19): “Obviously he must have certain technical knowledge: he must generally be a bit of a Linguist and more than a bit of Paleographer; sometimes a bit of an Architect; almost always a bit of a Book-binder, Librarian, Mycologist, and Photographer: must have a specialised smattering of the knowledge of many specialists. Moreover, in order to sort and list, he must understand his charges and this means that he must have some knowledge of the technique which produced them; if he is to take charge of the Archives of a Bank, or a Court of Law, or an Ice Cream Factory, he has got to have or acquire some knowledge of Dpuble Entry, the Common Law, or Chemistry; an deven more, perhaps, of the best approach to people who possess such knowledge more fully.

In another study, the basic technical skills that an archivist should have in the 21 st century were determined as follows (Şentürk, 2021, p. 116): 
- Archivist must be an expert in basic archival management functions.

- Archivist should have knowledge not only in archives management but also in records management.

- Archivist should know very well the organizational structure of the institution she/he works for, its units and the work done in the units.

- Archivist should have physical, intellectual and administrative control over the archive collection.

- Archivist should have knowledge of the legislation that is related to both archives management and the institution she/he works for.

- Archivist must be an expert in digital archive management.

- Archivist must be an expert in user relationship management and know the user well.

- Archivist should have information about new developments and applications related to archives management and follow the innovations.

Some of the studies that indirectly approach the subject of career in archives are related to archival education. It is observed that in these studies, emphasis is placed on archival competency and skills.

Archivist positions usually require a minimum education of at least one advanced degree. Moreover, the archivist learns about archival methods and standards by working in established archives with other professional archivists, and through continued education and training via seminars, workshops, conferences, and other professional development venues. The educated archivist belongs to professional organizations and keeps up with current trends and methods by reading professional literature and might have even obtained an archival certification (Osorio and Woodward, 2016, p. 143).

The body of knowledge that a student should master as part of a graduate archival education comprises core archival knowledge and complementary knowledge, both supplemented by ethical and public interest concerns. Core archival knowledge provides the theoretical and practical basis necessary to work as a professional archivist. This includes knowledge of archival ethics that promote responsibility toward the standards of the profession and the public good. Complementary knowledge introduces students to other disciplines, knowledge of which will deepen their understanding of archival work, support its accomplishment, and teach others how archives function for the public good. Complementary knowledge also allows students to specialize in specific aspects of archival work or to function in cross-disciplinary settings (SAA, 2021). 
Leadership is one of the most emphasized competencies for the 21 st century employee. In this context, leadership is one of the most important features that the archivist of this century should have. Leadership in archives was emphasized in a study as follows: "Archival leadership occurs on at least four key levels: in the archival repository, in the larger institutional setting, in the archival profession, at local, regional, and national levels, and in our public interactions with society" (Mariz and others, 2011, p. 115).

In addition to leadership, it is very important for the archivist to be strong primarily in communication within the scope of human skills, if not, to improve her/himself in this regard. Because archival profession is in a way about information service. Communication with the user is an important part of this profession. In addition to communication, the archivist should have the ability to empathize, be tolerant and patient, manage differences, etc. (Şentürk, 2021, p. 115).

It is another important issue for the archivist to be an expert in marketing and promotion in order to promote the archival material as wide as possible. In a study emphasizing this issue, it was stated that: "Advocacy skills are becoming increasingly essential for archivists to cultivate. As funding becomes more constricted, archivists will continue to find themselves required to argue for the value of their work" (Buchanan and others, 2017, p. 283).

In the literature, there are studies in which the skills and competencies that the archivist should have are presented as items. These studies can be grouped as scientific studies, studies of professional organizations and national career services.

In a study conducted in 2015, the skills that archivists determined for themselves are as follows under the title of "Archivistic Competences for Traditional Archives" (Vilar, 2015, p. 556):

- Organization of materials (How materials are organized in the archive, where located, do they exist).

- Regarding the archive as organization (Functioning, organization, formalities).

- For subject area (Specialization for certain subject and its creators, e.g., health sector).

- Description, processing of materials (How materials are processed, described).

- For history (General knowledge of the past).

- Ability to read documents (Old languages and scripts).

- Finding aids (Tools available for finding documents).

- Ability to interpret documents (Context, provenance). 
- Preservation of materials (How materials are handled to stay intact).

- For legislation relevant for archives (Laws on archives, on data security and preservation, copyright, etc.).

- Research (How research process, scientific writing is conducted).

- Pedagogical attitude (For teaching, consulting, helping users).

- For technical matters (Procedures e.g., scanning, copying).

- Literacy (Basic literacy skills acquired through education).

- Memory (Ability to memorize and recall information).

- Work with children (Specialization for work with young users).

- Responsibility (Acting responsibly regarding legislation and archival conventions).

- Communication (Skills necessary for good communication with the users).

- Foreign language skills (For work with foreign users).

In the handbook of the Academy of Certified Archivist, the topics that archivists should know are as follows (Academy of Certified Archivists, 2012, p. 18):

- The impact of social, cultural, economic, political, and technological factors on the evolution and characteristic of records and papers and their management.

- The origins, development, and definitions of archival concepts, terms, principles, practices and methods.

- The development of archival institutions and programs in society.

- The similarities and differences between the nature and administration of organizational records and personal papers.

- The physical and technological characteristics of records and papers and how these characteristics influence their appraisal, acquisition, preservation, and use.

- Archival theory, methodology, and practice appropriate for records and papers on all media: paper, digital, audio, and visual.

- The standards and accepted professional best practices that apply to archival work, including their rationale and implications.

- The concepts of the life cycle of records and the records continuum.

- The relationship between accepted professional policies and practices and institutional applications of these policies and practices. 
- How the core archival functions (selection, appraisal, and acquisition; arrangement and description; reference services and access; preservation and protection; and outreach, advocacy and promotion) relate to each other and influence the administration of records and papers.

- The different institutional settings in which archival programs may exist and the implications of placement within a particular institution.

- How the administration of archives is related to, different from, and draws upon the theory, methodology, and practice of such allied professions and disciplines as: history, library and information science, records management, museology, historic preservation, historical editing, and oral history.

- How archival theory, methodology, and practice have been influenced and affected by computer technologies and applications such as electronic communication, including e-mail; and online information exchange, including the World Wide Web.

The points highlighted by ARA (Archives and Records Associations) under the title of 'The Skills' are as follows (https://www.archives.org.uk/careers/careers-in-archives.html, 8.7.2021):

- Good with people: archivists meet and work with many different people and need the ability to relate to and encourage them all.

- Forward thinking: our demands for and use of information are constantly changing: archivists need to be able to anticipate these changes and to prepare to meet the challenges they bring.

- Logical: archives need identifying and sorting before they can be effectively interpreted or used.

- Able to undertake research: archivists are not researchers but may occasionally need to research in order to interpret archives; an understanding of research skills is also helpful for advising users. An interest in history is often advantageous, although many archivists possess degrees in other disciplines.

- Committed to professional development: archivists need to be prepared to continue their development after qualification, acquiring management skills and skills which enable them to play a full part in the development of the heritage sector.

- Comfortable with new technology: you will need to demonstrate the ability to use and adapt to rapidly evolving ICT (Information Communication Technology) packages and systems.

The skills and knowledge determined by the UK National Careers Service for the 'Archivist' are as follows (https://nationalcareers.service.gov.uk/job-profiles/archivist, 8.7.2021): 
- To be thorough and pay attention to detail,

- An interest and knowledge of history,

- Analytical thinking skills,

- Administration skills,

- The ability to use your initiative,

- Customer service skills,

- The ability to work well with others,

- Concentration skills and

- To be able to use a computer and the main software packages confidently.

In addition to skills and knowledge, the following responsibilities have been determined under the title of 'day to day tasks':

- Store materials correctly and keep them in good condition.

- Use archive management software to date, catalogue and index materials.

- Create and set up programmes to digitise records and materials.

- Help people use the archives.

- Make records available to users in formats such as photocopies, microfiche and online.

- Carry out research.

- Give talks and organise presentations, displays and exhibitions and

- Negotiate the buying or donation of archive material

At The San José State University School of Information's 'MLIS Skills at Work Report' which is about the latest career trends for information professionals the skills are determined as follows (2021, p. 6):

- Interpersonal communication, problem-solving, customer relations and teamwork skills, and the ability to demonstrate a positive and enthusiastic commitment to public service.

- Outreach, marketing, grant writing, fund development, budgeting, and financial management.

- Collaborative, innovative, forward-thinking, and open to uncertainty and ambiguity, aware of new trends and emerging technologiesto thrive in a complex, changing environment.

- Gather, appraise, organize, analyze, and disseminate informationin a smart, concise, and digestible way. 
In this study, 'Skills and Competencies of the 21st Century Archivist' were compiled under three main headings as: technical, managerial and communication.

Table 2. Skills and competencies of the 21 st century archivist

\begin{tabular}{|c|c|}
\hline Category & Areas of Competency and Skills \\
\hline 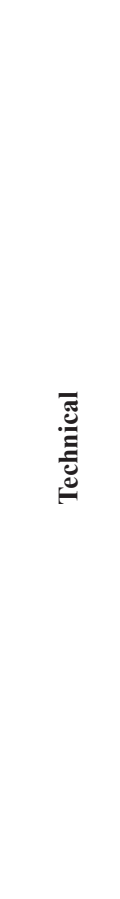 & 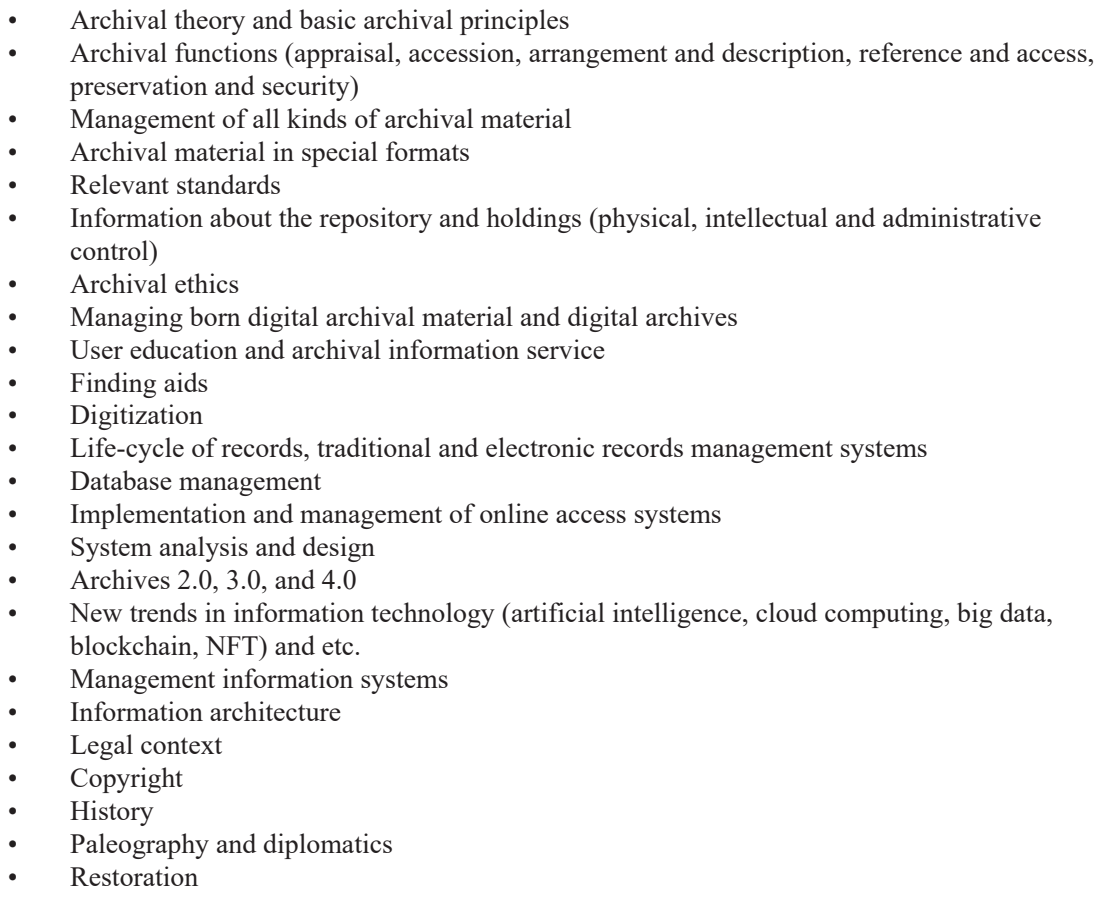 \\
\hline 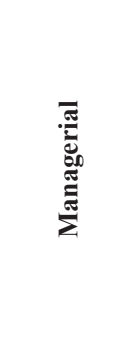 & $\begin{array}{ll}\text { - } & \text { Functions of management (planning, organizing, staffing, directing, controlling) } \\
\text { - } & \text { Advocacy and marketing } \\
\text { - } & \text { Analegic thinking, management and planning } \\
\text { - } & \text { Human resource management (career management) } \\
\text { - } & \text { Budgeting } \\
\text { - } & \text { Effective decision making } \\
\text { - } & \text { Using initiative } \\
\text { - } & \text { Effective project management } \\
\text { - } & \text { Effective reporting }\end{array}$ \\
\hline 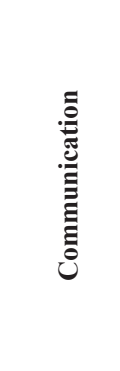 & $\begin{array}{ll}\text { - } & \text { Leadership } \\
\text { - } & \text { Empathy } \\
\text { - } & \text { Activation listening } \\
\text { - } & \text { User relations } \\
\text { - } & \text { Foreign language } \\
\text { - } & \text { Effective oral and written communication } \\
\text { - } & \text { Body language } \\
\text { - } & \text { Media skills } \\
\text { - Stress management }\end{array}$ \\
\hline
\end{tabular}




\subsection{The Road to Success}

The basis of today's corporate-employee relationship is the orientation of the employee to a job that will make them happy. This is one of the basic principles of corporate career management. Because as long as people do the job that makes them happy, their motivation and performance will be high. Thus, the performance of the institution and the rate of profitability increases. At this point, the necessity of 'self-knowledge' as an important point of career management and planning emerges.

The path to be followed to be a successful archivist is almost the same as for other professions. The difference is in the technical elements of the profession.

The profession in archives management is one of the professions that cannot be successful without love. Thus in order to be a successful archivist in the 21 st century, it is necessary to love archives management and archival material first.

The 21 st century has created both opportunities and threats for all professions. It is very important to be aware of the opportunities and threats that arise in order to be successful in the profession and to act accordingly in the career path. Hickerson (2001, pp. 7-16) describes the challenges that the 21 st century archivist should consider as follows:

- Managing the identification, appraisal, retention, preservation, and provision of support for the use of documents generated in electronic form,

- Devoting greater resources to non-textual holdings,

- Recognizing that records are global,

- Devising new methods for describing and providing user access to the everexpanding volume of contemporary records in all formats,

- Making our holdings more accessible to and usable by our core constituencies and broadening use by expanded audiences,

- Expanding the scope of our collection development priorities,

- Generating more basic and applied research on archival aspects of information management,

- Strengthening our national archival organization,

- Augmenting the range of skills, knowledge, and resources engaged in the archival enterprise and

- Maintaining the credibility of our role as respected evidentiary authorities and as trusted guarantors of society's interests, today and in the future. 
In the changing world and career environment, employees must draw their own career paths. It is necessary to have lots of equipment to be successful in whatever kind of profession we perform, including technical professions. Before, technical knowledge and skills were at the forefront in order to be successful in the profession. However, today, it can be said that technical knowledge and skills give priority to managerial and communication skills.

In the previous part of the study, "Skills and Competencies of the 21 st Century Archivist" were presented. In addition to the skills and competencies, the basic principles and issues that a successful archivist should consider in their career path are presented in this study as:

- The archivist must be visionary and approach events from a broad perspective.

- The archivist must take responsibility for managing her/his own career.

- The archivist should make career planning. While planning, should benefit from the SWOT analysis and other techniques and correctly identify, focus on the opportunities and threats in the field.

- The archivist should set SMART (Specific, Measurable, Attainable, Realistic, Timebased) goals and act in line with these goals.

- The archivist should work on the skills and competencies she/he should have. She/he must constantly improve her/himself.

- The archivist should have experience in physical archives. She/he should be experience oriented and give priority to job specific experience.

- The archivist should keep up with current archival trends and methods.

- The archivist should be at peace with technology.

- The archivist should be active in the field (being a member of institutions and organizations, correspondence groups related to the field).

- The archivist should be user-oriented.

- Networking is the magic term of the new generation career. The archivist should have a wide communication network.

- The archivist should adopt lifelong learning as a principle.

- The archivist should receive training on such subjects as foreign language, marketing and user relations management, time management, stress management, project management, effective reporting, effective presentation, communication and body language, and improve her/himself.

- The archivist should have an an excellent resume and 
- The archivist should use her/his time outside of work effectively and develop a hobby.

In short, archivists should adopt the principle of being effective and competent in all kinds of business processes. As Millar points out (2017, p. 60);

Archivists have, in the last three decades, developed descriptive, preservation and recordkeeping standards, constructed online databases and expanded the reach of our professional associations to address not just historical archives care but the broad sweep of records and archives management. We should not forget these archival successes. But archivists also have to lift ourselves out of our analogue environment and focus more effort on forging a new path - if we can keep playing with that metaphor - to reposition our world, including archives, archival institutions and archival practitioners, more strategically for the future. To do this, we need to take a step back and remember that we are not sitting on the apex of achievement but on the crest of a wave.

\section{Discussion and Recommendations for Future}

There are two facts about the archivist's career that can be emphasized. Firstly, archival profession will exist for many years, even though there are changes in archivist's portrait in time. Secondly, archival profession is influenced by all the new generation processes. Therefore, archivists should not stand still. They must constantly change and progress. At this point, archivists, educators and professional organizations have lots of responsibilities. In this sense, things that can be done at the starting point has been determined as follows within the scope of this study:

- In every country, people who wants to work as "Archivist" must take the exam on archives management, take the relevant certificate, and renew this certificate periodically (as practiced in the USA under the leadership of the Society of American Archivists).

- The associations and organizations on archival profession of each country must be active and have a wide sphere of influence. They should advise archivists on career management.

- Comprehensive training programs should be organized for archivists working in private or public institutions.

- In undergraduate and graduate programs that provide archival education, it should be aimed to gain technical skills and knowledge, as well as focusing on managerial and communication skills and competencies.

- When archivists have the prestige and importance they deserve, they will believe in their profession more and therefore their motivation will increase. National archives, which are the most important institutions representing the archival profession in this regard, has responsibilities. 
- National archives should lead the way in organizing all kinds of activities, projects, etc. that will impose the importance and necessity of archivist and archival material on the society.

- National archives should give active support to education. This strategy is very important because it will raise positive awareness towards archives and the archival profession.

- National archives should lead the way in organizing training programs and developing standards for the necessary skills and competencies of the archival profession.

\section{CONCLUSION}

When people realize the importance of their work and internalize it, they first respect their work and then they love their work. The most important thing that people who works as archivist should not forget is that archival profession is very important for mankind. At this point, it should be strongly argued that; the successful archivist must defend and internalize the archiving mission instinctively.

In addition to defending and internalizing the archival mission, it would be best for archivists to develop themselves in line with the changing world conditions and to have a visionary perspective. Because the archival profession will exist as long as human beings exist. In this context; archivists should not forget that they are the managers of memory and they need to be the masters of their own disciplines.

Peer-review: Externally peer-reviewed.

Conflict of Interest: The author has no conflict of interest to declare.

Grant Support: The author declared that this study has received no financial support.

Hakem Değerlendirmesi: Dış bağımsız.

Çıkar Çatışması: Yazar çıkar çatışması bildirmemiştir.

Finansal Destek: Yazar bu çalışma için finansal destek almadığını beyan etmiştir.

\section{References/Kaynakça}

Academy of Certified Archivists. (2012). Handbook for archival certification. Newyork: Academy of Certified Archivists.

Archivist. (2021). Retrieved July 8, 2021, from https://nationalcareers.service.gov.uk/job-profiles/archivist

Brewer, A. M. (2020). Careers: Thinking, strategising and prototyping. Bingley: Emerald Publishing Limited.

Buchanan, S., Gruning, J., Gursoy, A. and Barker, L. (2017). Surveying archivists and their work toward advocacy and management, or "enterprise archiving". The American Archivist, 80(2): 268-295. doi: https:// doi.org/10.17723/0360-9081-80.2.268

Careers in archives. (2021). Retrieved July 8, 2021, from https://www.archives.org.uk/careers/careers-inarchives.html 
Cicek, B. (2021). Contemporary career approaches for the needs of today's individuals and organizations. In M. A. Türkmenoğlu and B. Çiçek (Ed.), Contemporary Global Issues in Human Resource Management (pp. 9-22). Bingley: Emerald Publishing Limited.

Craven, L. (2008). From the archivist's cardigan to the very dead sheep: What are archives? What are archivists? What do they do? In L. Craven (Ed.), What are Archives?: Cultural and Theoretical Perspectives: A Reader (pp. 7-30). GBR: Ashgate Publishing.

Dearstyne, B. W. (1993). The archvial enterprise. Chicago: American Library Association.

Dearstyne, B. W. (2021). The archival profession: Meeting critical institutional and social needs. Retrieved from https://www.certifiedarchivists.org/other-resources/articles/the-archival-profession-meeting-criticalinstitutional-and-social-needs/

Donohue, R. and Tham, T. L. (2019). Career management in the 21st century. In P. Holland (Ed.), Contemporary HRM Issues in the 21st Century (pp. 51-68). Bingley: Emerald Publishing Limited.

Eastwood, T. (1993). Educating archivists about information technology. American Archivist, 56(3), 458-466. http://www.jstor.org/stable/40294427

GPAS curriculum. (2021) Retrieved August 3, 2021, from https://www2.archivists.org/prof-education/graduate/ gpas/curriculum

Hecklaua, F., Galeitzkea, M., Flachsa, S. and Holger Kohlb, H. (2016). Holistic approach for human resource management in Industry 4.0. Procedia CIRP, 54, 1-6. doi.org/10.1016/j.procir.2016.05.102

Hickerson, H. T. (2001). Ten challenges for the archival profession. The American Archivist, 64(1), 6-16. doi:10.17723/aarc.64.1.0rg6525nu1437v31

Italian archivists manifesto 2016. (2019) Retrieved April 19, 2019, from https://www.ica.org/sites/default/ files/Manifesto_Italian_archivists_ENG.pdf

Jenkinson, H. (1965). A manual of archive administration. Oxford: Clarendon Press.

Jenkinson, H. (1984). Reflections of an archivist. In M. F. Daniels and T. Walch (Ed.), A Modern Archives Reader: Basic Reading on Archival Theory and Practice (pp. 15-21). Washington: National Archives and Records Services.

Levine-Clark, M. and Carter, T. M. (Ed.). (2013). ALA Glossary of Library and Information Science. Chicago: ALA.

Mariz, G., McCrea, D. E., Hackman, L. J., Kurtz, T., \& Jimerson, R. C. (2011). Leadership skills for archivists. The American Archivist, 74(1), 102-122. http://www.jstor.org/stable/23079003

Millar, L. (2017). On the crest of a wave: Transforming the archival future. Archives and Manuscripts, 45(2), 59-76. doi.org/10.1080/01576895.2017.1328696

Osorio, S. and Woodward, E. (2016). Archival malfeasants and the amateur archivist: The case for a professionally trained archivist. Journal of Archival Organization, 13(3-4), 142-145. doi.org/10.1080/15332748.2018. 1444440

Pearce-Moses, R. (Ed.). (2005). A glossary of archival and records terminology. Chicago: The Society of American Archivists.

Peters, T. (2021). Resilience and black swans. Retrieved from https://tompeters.com/2008/05/resilience-andblack-swans/

Stevenson, J. (2008). The online archivist: A positive approach to the digital information age. In L. Craven (Ed.), What are Archives?: Cultural and Theoretical Perspectives: A Reader (pp. 88-106). GBR: Ashgate Publishing. 
Şentürk, B. (2021). Arşivcilik: Geçmişin izlerinden geleceğin pusulalarına. İstanbul: Hiperyayın.

The San José State University School of Information. (2021, June 5). MLIS skills at work: A snapshot of job postings, Retrieved June 5, 2021, from https://ischool.sjsu.edu/sites/main/files/file-attachments/ career_trends.pdf

Vilar, P. and Sauperl, A. (2015). Archives, quo vadis et cum quibus?: Archivists' self-perceptions and perceptions of users of contemporary archives. International Journal of Information Management, 35, 551-560. doi. org/10.1016/j.ijinfomgt.2015.06.001

Williams, C. (2006). Managing archives: foundations, principles and practice. Oxford: Chandos Publishing. 